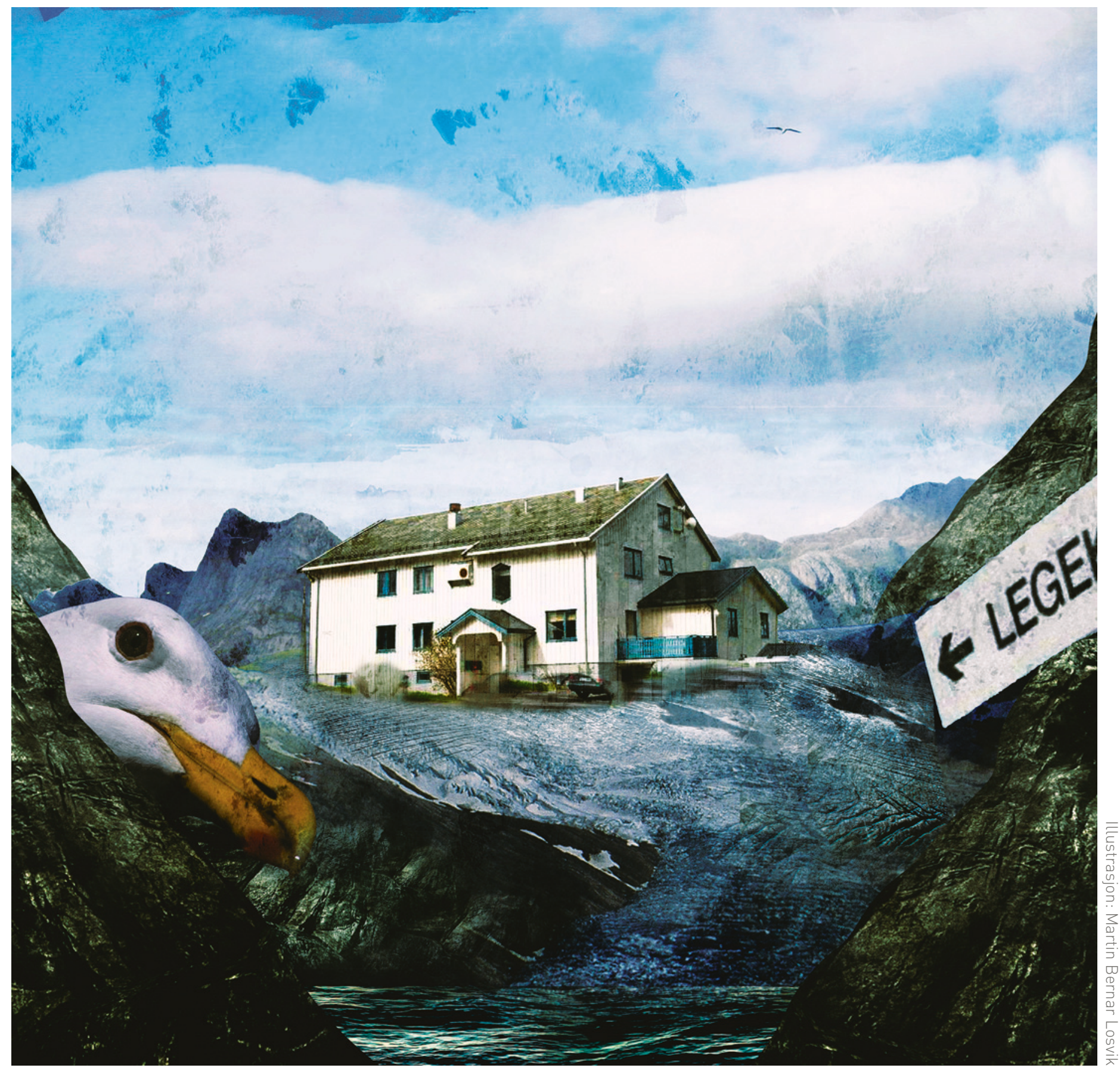

\title{
Legekontoret i Engavågen
}

1. Engavågen er en bygd sør i Meløy kommune i Nordland. Den ligger omtrent 20 mil sør for Bodø
og drøyt to mil fra Svartisen. Det er rundt 850 innbyggere i bygda, og på legekontoret jobber 1 -2 leger.
Kontorbygningen var opprinnelig fødestue. 